\title{
Novel $\beta$ - $N$-acetylglucosaminidases from Vibrio harveyi 650: Cloning, expression, enzymatic properties, and subsite identification
}

\author{
Wipa Suginta ${ }^{*}$, Duangkamon Chuenark', Mamiko Mizuhara², Tamo Fukamizo²
}

\begin{abstract}
Background: Since chitin is a highly abundant natural biopolymer, many attempts have been made to convert this insoluble polysaccharide into commercially valuable products using chitinases and $\beta$ - $N$-acetylglucosaminidases (GlcNAcases). We have previously reported the structure and function of chitinase A from Vibrio harveyi 650. This study $t$ reports the identification of two GIcNAcases from the same organism and their detailed functional characterization.

Results: The genes encoding two new members of family-20 GlcNAcases were isolated from the genome of $V$. harveyi 650, cloned and expressed at a high level in E. coli. VhNag1 has a molecular mass of $89 \mathrm{kDa}$ and an optimum pH of 7.5, whereas VhNag2 has a molecular mass of $73 \mathrm{kDa}$ and an optimum pH of 7.0. The recombinant GlcNAcases were found to hydrolyze all the natural substrates, VhNag2 being ten-fold more active than VhNag1. Product analysis by TLC and quantitative HPLC suggested that VhNag2 degraded chitooligosaccharides in a sequential manner, its highest activity being with chitotetraose. Kinetic modeling of the enzymic reaction revealed that binding at subsites $(-2)$ and $(+4)$ had unfavorable (positive) binding free energy changes and that the binding pocket of VhNag2 contains four GlcNAc binding subsites, designated $(-1),(+1),(+2)$, and $(+3)$.

Conclusions: Two novel GlcNAcases were identified as exolytic enzymes that degraded chitin oligosaccharides, releasing GICNAc as the end product. In living cells, these intracellular enzymes may work after endolytic chitinases to complete chitin degradation. The availability of the two GlcNAcases, together with the previously-reported chitinase A from the same organism, suggests that a systematic development of the chitin-degrading enzymes may provide a valuable tool in commercial chitin bioconversion.
\end{abstract}

\section{Background}

Chitin is a $\beta$-1,4-linked homopolymer of $N$-acetylglucosamine (GlcNAc), which is found mainly in the exoskeleton of crustaceans, insects and in the cell walls of fungi. Chitin is one of the most abundant polymers in nature and its degradation derivatives are pharmaceutically valuable. for example, chitoligosaccharides can stimulate the immune system to respond to microbial infections and chitin monomers have been shown to act as anti-aging and anti-tumor agents, as well as to relieve the symptoms of osteoarthritis [1-6]. Complete

\footnotetext{
* Correspondence: wipa@sut.ac.th

'Biochemistry-Electrochemistry Research Unit, Schools of Chemistry and Biochemistry, Institute of Science, Suranaree University of Technology, Nakhon Ratchasima 30000, Thailand Full list of author information is available at the end of the article
}

degradation of chitin requires chitinases (EC 3.2.1.14) and $\beta$ - $N$-acetylglucosaminidases (GlcNAcases) or chitobiases (EC 3.2.1.52), so such enzymes could potentially serve as biocatalysts in the production of chitin derivatives of desired sizes during the recycling of chitin biomass.

As well as functioning in chitin degradation by bacteria, GlcNAcases are also known to be key enzymes in the catabolism of glycoconjugates containing $\mathrm{N}$-acetylglucosamine residues $[7,8]$ and mutations of the gene encoding a human GlcNAcase homologue (HexA) cause a fatal genetic lipid storage disorder, known as TaySachs disease [9]. In the CAZy database (http://www. cazy.org), GlcNAcases are classified into glycosyl hydrolases family 3 (GH-3) or family 20 (GH-20), which differ in sequence and mode of enzyme action [10,11]. Family-3
C Biomed Central 
GlcNAcases are thought to act by a standard retaining mechanism involving a covalent glycosyl-enzyme intermediate while family-20 enzymes employ a 'substrateassisted' mechanism involving the transient formation of an oxazolinium ion intermediate [12-15]. Most of the GlcNAcases described hitherto belong to the GH20 family. To date, only five bacterial GH-3 GlcNAcases have been characterized, including NagZ or ExoII from Vibrio furnissii [16], Nag3A from Clostridium paraputrificum M-2 [17], NagA from Streptomyces thermoviolaceus [18], and NagA and CbsA from Thermotoga maritima and T. neapolitana [19].

Vibrio harveyi, formerly known as $V$. carchariae, is a Gram-negative marine bacterium that causes luminous Vibriosis, a serious disease that affects commercially farmed fish and shellfish species [20,21]. We previously reported isolation of the gene encoding endochitinase $\mathrm{A}$ from Vibrio harveyi type strain 650 for functional and structural characterization $[22,23]$. In this study, we employed a homology-based strategy to isolate two GlcNAcase genes from the genome of the same Vibrio strain. Sequence analysis suggested that the resultant polypeptides were new members of the GH-20 family. Enzymic properties of the GlcNAcases expressed in $E$. coli were investigated. Their kinetic properties and identification of the subsites in the more active enzyme are discussed in further detail.

\section{Results and Discussion}

\section{Gene isolation and sequence analysis}

The availability of the complete genome sequence allowed us to locate three open reading frames (ORFs), including VIBHAR_03430 (Swiss-Prot: A7MYY8), VIBHAR_06345 (Swiss-Prot: A7N8P3) and, VIBHAR_01265 (Swiss-Prot: A7N1G4) in the genome of $V$. harveyi type strain ATCC BAA-1116 BB120. These reading frames encode uncharacterized proteins with presumed GlcNAcase activity. In an attempt to isolate the genes that encode GlcNAcases in a closely-related organism, three sets of oligonucleotides were designed based on the above-mentioned ORFs. Two homologous DNAs were amplified by the oligonucleotides designed from the VIBHAR_03430 and VIBHAR_01265 ORFs, whereas the DNA fragment compatible with the VIBHAR_06345 ORF could not be amplified successfully. Hence, the first two DNA fragments (hereafter referred to as VhNag1 and VhNag2) were further cloned and expressed for functional characterization. Nucleotide sequence analysis showed that the $V h N a g 1$ full-length DNA contains 2,343 bp which encode a polypeptide of $88,849 \mathrm{Da}$, whereas the $V h N a g 2$ full-length DNA contains $1,926 \mathrm{bp}$, encoding a polypeptide of 73,143 Da. The $p$ I values of $V h N a g 1$ and $V h N a g 2$ were calculated to be 4.9 and 5.4, respectively. The nucleotide and corresponding amino acid sequences of the newly-identified GlcNACases have been deposited in the GenBank/ EMBL/DDBJ database with assigned accession numbers of HM175715 for $V h N a g 1$ and HM175716 for VhNag2. Although a BLAST search indicated high sequence similarity of $V h N a g 1$ and $V h N a g 2$ to GlcNAcases from other Vibrio species, most of these sequences turned out to be only hypothetical proteins with predicted GlcNAcase activity. Low sequence similarity with all GH-3 members $(<12 \%)$ suggested that neither of these enzymes belong to $\mathrm{GH}-3$, but matches of up to $30 \%$ with previously studied GH-20 enzymes indicated that they are new GH-20 members. A sequence comparison with eleven functionally-characterized GH-20 enzymes (data not shown) shows that both $V h N a g$ sequences are closest to the $\alpha$-chain of human GlcNAcase (HuHexA, $30 \%$ similarity) [24], followed by Serratia marcescens chitobiase ( $\mathrm{SmChb}, 24 \%)$ [25]. Fig. 1 shows a sequence alignment of $V h N a g 1$ and $V h N a g 2$ with three selected GlcNAcases, including $V h C h b$ [26] (the only characterized GlcNAcase from $V$. harveyi), HuHexA and $S m \mathrm{Chb}$ (which have the highest sequence similarities to the $V h N a g$ sequences). Since the structural details of $\mathrm{SmChb}$ are well studied, further sequence comparisons were with $S m C h b$. As seen in Fig. 1, a number of consensus residues are identified, a few of which may participate in the catalytic function of the Vibrio GlcNAcases. The most obvious of these are the acidic pairs Asp287-Glu288 (in VhNag1) or Asp437-Glu438 (in VhNag2) (Fig. 1, red asterisks) as they are completely aligned with Asp539-Glu540 of $S m$ Chb. These two residues were previously shown to be crucial for the catalytic function of $S m \mathrm{Chb}$, Glu540 acting as the catalytic residue $[13,25]$. Other residues found to be involved in binding the substrate in the enzyme-substrate complex of SmChb-diNAG include Asp346, Arg349, Asp378, Asp379, Trp616, Trp685, and Trp737. These residues are completely conserved among the GlcNAcase species (Fig. 1, blue dots).

\section{Recombinant expression and mass identification}

The full-length VhNAg1 and VhNag2 DNAs were subsequently cloned into the $\mathrm{pQE60}$ expression vector, which provides high-level expression in E. coli M15 of $C$-terminally (His) ${ }_{6}$-tagged polypeptides. The overall yields of the purified recombinant proteins obtained after Ni-NTA affinity chromatography were $5-10 \mathrm{mg} /$ $\mathrm{ml}$ of bacterial culture. Fig. 2A shows SDS-PAGE analysis, displaying a single band of $V h N a g 1$ migrating to slightly below the $96 \mathrm{kDa}$ marker and $V h \mathrm{Nag} 2$ closer 66 $\mathrm{kDa}$. The molecular masses estimated from their mobilities are consistent with the theoretical masses of the enzymes $(88,849 \mathrm{Da}$ for $V h \mathrm{Nag} 1$ and 73,143 $\mathrm{Da}$ for VhNag2). In peptide mass fingerprinting, 9 and 13 


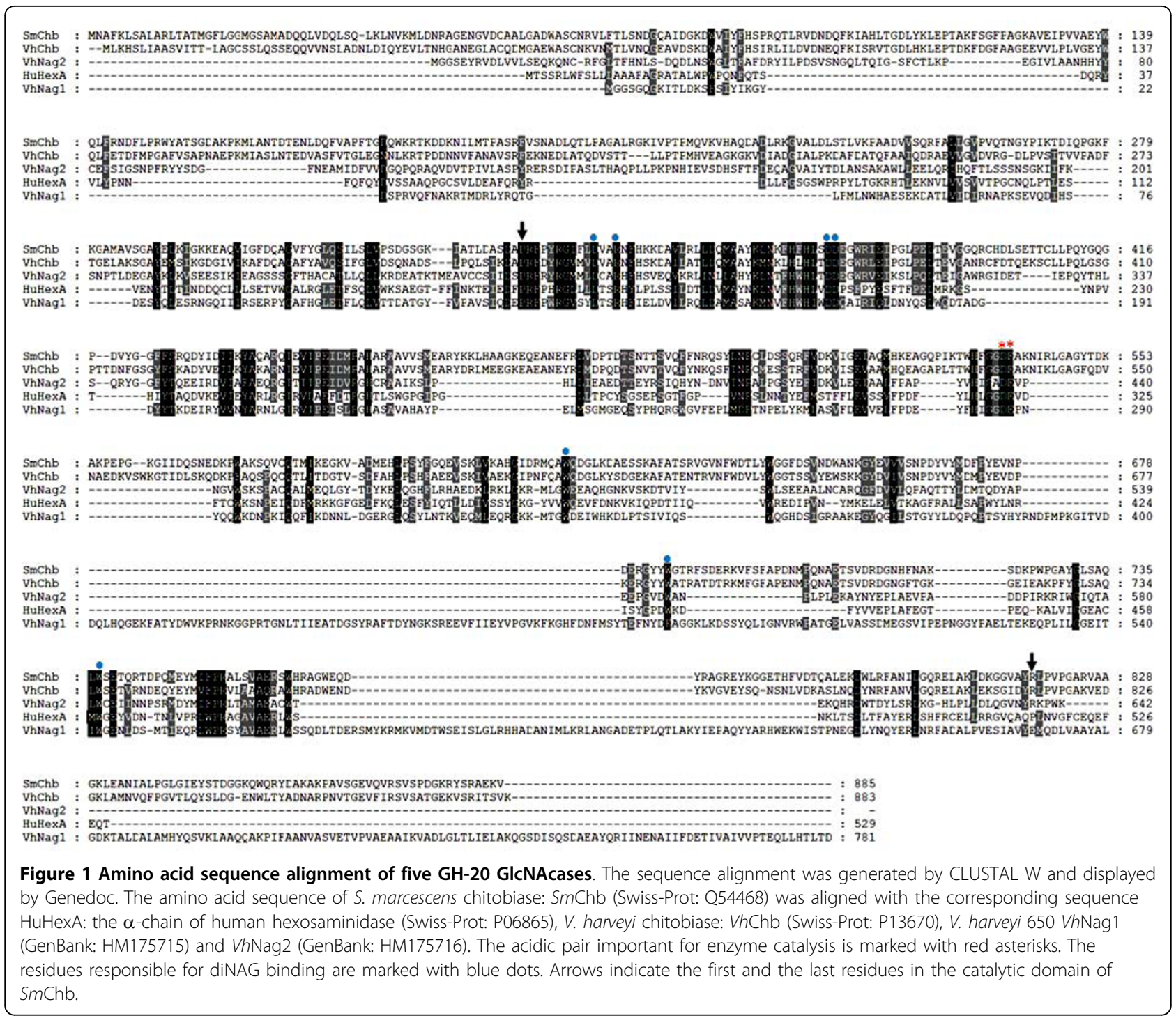

$V h$ Nag1 peptides unambiguously matched internal peptides of GlcNAcases from $V$. angustum and Photobacterium $s p$, respectively. For $V h N a g 2,20$ and 21 peptides were identical with the internal peptides of $V$. parahaemolyticus and $V$. alginolyticus GlcNAcases (see additional file 1, Table S1). This peptide mass identification strongly indicates that the proteins expressed in E. coli are GlcNAcases.

\section{Assessment of GlcNAcase activity and kinetic studies}

Both of the purified GlcNAcases were active against $p$ NP-GlcNAc, but $V h N a g 2$ was found to be much more active than $V h N a g 1$. We suspect that the full-length $V h N a g 1$ is expressed as a pro-enzyme, which requires proteolytic processing to attain its full activity. The hydrolysis of $p$ NP-GlcNAc by $V h N a g 1$ and $V h N a g 2$ was determined as a function of time (additional file 2, Fig. S1).
VhNag2 activity was significantly greater than that of $V h N a g 1$ over the entire course of reaction. In the reaction progress curves, the activity of both enzymes was constant for up to $15 \mathrm{~min}$, and then began to decrease at longer incubation times. Therefore, the reaction time was set to $10 \mathrm{~min}$ to ensure that initial velocities were measured in subsequent kinetic experiments.

The effect of $\mathrm{pH}$ on GlcNAcase activity was examined with $p$ NP-GlcNAc as substrate. The $\mathrm{pH}$ activity profiles of $V h N a g 1$ and $V h N a g 2$ were typical bell-shaped curves as seen for most glycosyl hydrolases. Fig. 2B shows enzymic activity decreasing at low and high $\mathrm{pH}$ values. The maximal activity of $V h N a g 1$ was at $\mathrm{pH} 7.5$ and of $V h \mathrm{Nag} 2$ at $\mathrm{pH}$ 7.0. When specific hydrolytic activity was determined with various substrates (Fig. 3), $p$ NPGlcNAc was found to be the most effective. While $V h N a g 2$ could hydrolyze all the three $p \mathrm{NP}$-glycosides 


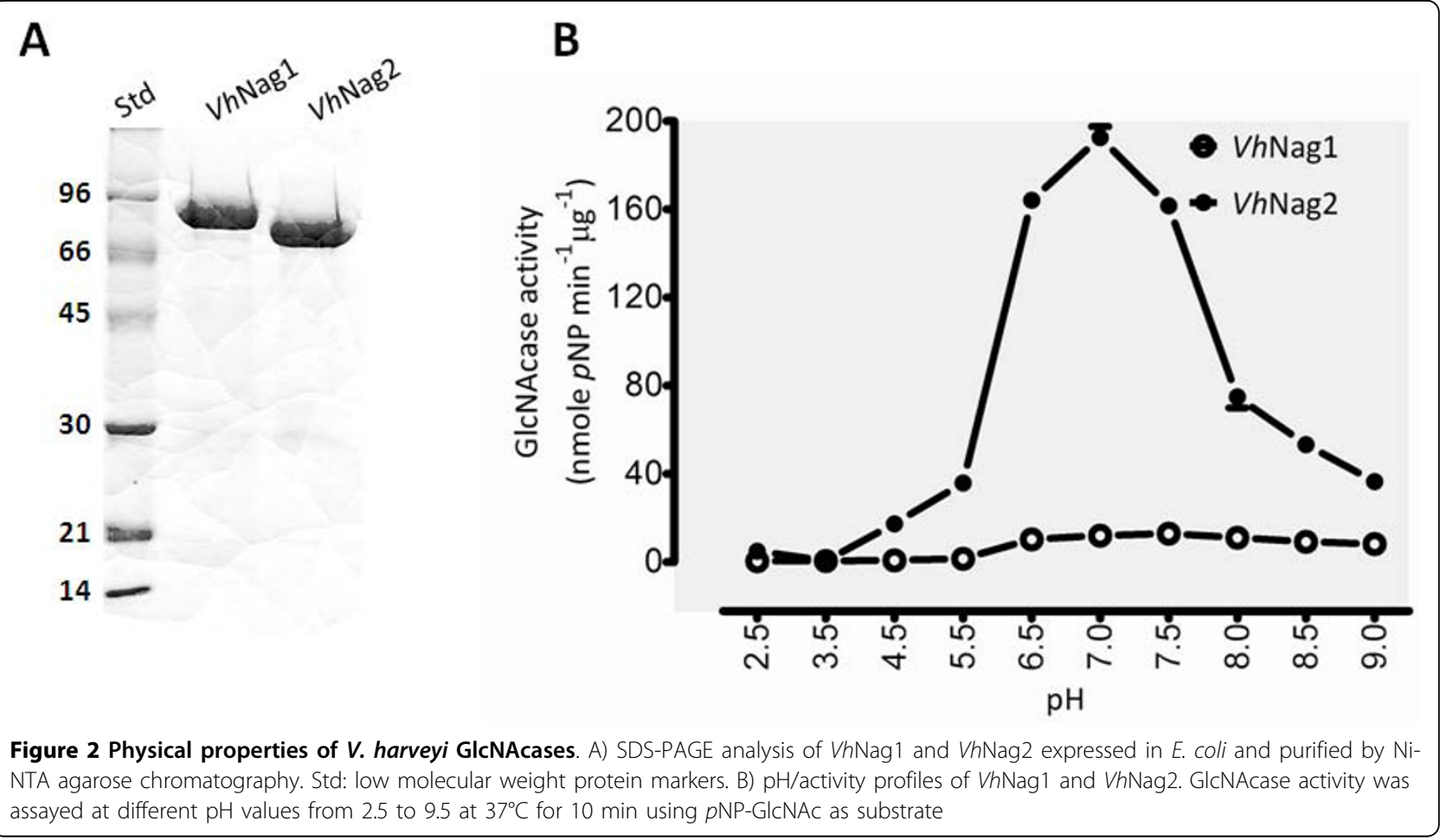

(although $p \mathrm{NP}$-GlcNAc 2 and $p \mathrm{NP}$-Glucose were respectively hydrolyzed 300 -fold and 700-fold less efficiently than $p$ NP-GlcNAc), VhNag1 was only active with $p$ NPGlcNAc. Both enzymes could hydrolyze chitooligosaccharides $\left(\mathrm{GlcNAc}_{2-6}\right)$ and colloidal chitin with $V h N a g 2$ being at least ten-times more active than $V h N a g 1$. Of the natural glycosides, chitotetraose was the best substrate and chitotriose the second best. In contrast, chitobiose, chitopentaose and chitohexaose were only fair

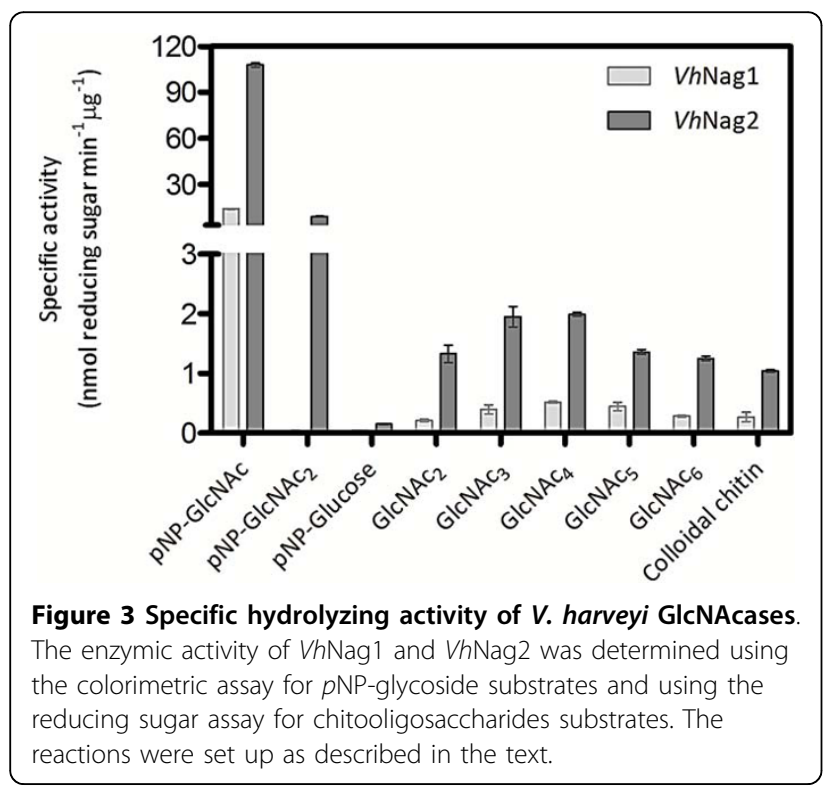

substrates, and insoluble (colloidal) chitin was the poorest of all (Fig. 3).

The kinetic parameters of the hydrolytic activity of the two GlcNAcases were further assessed. As shown in Table $1, k_{\text {cat }} / K_{\mathrm{m}}$ with $p$ NP-GlcNAc was 11 -fold greater for $V h N a g 2$ than for $V h N a g 1$. It was noted throughout this study that VhNag1 was tended to undergo rapid and progressive loss of GlcNAcase activity. Although several attempts were made to obtain the kinetic values of this higher- $\mathrm{M}_{r}$ enzyme, the data acquired with VhNag1 could not be evaluated precisely, and we decided not to present it in this study. In accordance

Table 1 Kinetic parameters of chitin oligosaccharide hydrolysis

\begin{tabular}{|c|c|c|c|}
\hline Substrate & $K_{\mathrm{m}}(\mu \mathrm{M})$ & $k_{\text {cat }}\left(\mathrm{s}^{-1}\right)$ & $k_{\text {cat }} / K_{\mathrm{m}}\left(\mathrm{M}^{-1} \mathrm{~s}^{-1}\right)$ \\
\hline pNP-GlcNAc (VhNag1) & $172 \pm 48^{a}$ & 0.08 & 465 \\
\hline pNP-GIcNAc(VhNag2) & $77 \pm 17$ & 0.38 & 4,935 \\
\hline $\mathrm{GlcNAC}_{2}$ & $179 \pm 52$ & 0.01 & 56 \\
\hline $\mathrm{GlCNAC}_{3}$ & $441 \pm 98$ & 0.10 & 228 \\
\hline $\mathrm{GlCNAC}_{4}$ & $329 \pm 93$ & 0.10 & 304 \\
\hline $\mathrm{GlCNAC}_{5}$ & $496 \pm 78$ & 0.09 & 181 \\
\hline $\mathrm{GlCNAC}_{6}$ & $421 \pm 76$ & 0.07 & 166 \\
\hline
\end{tabular}

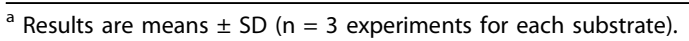

The initial velocity of the reaction catalyzed by $V$. harveyi GlcNAcases was measured at $37^{\circ} \mathrm{C}, 10 \mathrm{~min}$ with varied concentrations of chitin oligosaccharides from $0-500 \mu \mathrm{M}$. The release of products was determined by the reducing sugar assay (see text). The kinetic experiments were carried out in triplicate. The kinetic parameters $\left(K_{\mathrm{m}}, k_{\mathrm{cat}}\right.$, and $\left.k_{\text {cat }} / K_{\mathrm{m}}\right)$ were estimated from a non-linear regression function available in GraphPad Prism v.5.0. 
with our earlier demonstration (see Fig. 3), VhNag2 had the lowest $K_{\mathrm{m}}$ and highest $k_{\mathrm{cat}}$, yielding overall $k_{\mathrm{cat}} / K_{\mathrm{m}}$ of $4,935 \mathrm{M}^{-1} \mathrm{~s}^{-1}$ towards $p$ NP-GlcNAc. When natural substrates were compared, VhNag2 had the greatest catalytic activity with $\operatorname{GlcNAc}_{4}\left(k_{\mathrm{cat}} / K_{\mathrm{m}} 304 \mathrm{M}^{-1} \mathrm{~s}^{-1}\right)$, followed by GlcNAc $3\left(228 \mathrm{M}^{-1} \mathrm{~s}^{-1}\right)$, GlcNAc $5\left(181 \mathrm{M}^{-1} \mathrm{~s}^{-1}\right)$, $\operatorname{GlcNAc}_{6}\left(166 \mathrm{M}^{-1} \mathrm{~s}^{-1}\right)$, and GlcNAc $2\left(56 \mathrm{M}^{-1} \mathrm{~s}^{-1}\right)$. Overall, $k_{\text {cat }} / K_{\mathrm{m}}$ of $V h$ Nag2 with $p$ NP-GlcNAc is 88 -fold greater than with $\mathrm{GlcNAc}_{2}$ (the poorest glycoside substrate) and 16-fold greater than with $\mathrm{GlNAAc}_{4}$ (the best glycoside substrate). In general, the glycosidic bond of $p$ NP-GlcNAc is more easily cleaved than that of GlcNAc-GlcNAc, because of the higher electron-withdrawing capacity of $p$-nitrophenyl moiety. However, the rate of hydrolysis of $p$-nitrophenyl glycoside depends on the affinity to the enzyme used. For example, Keyhani \& Roseman [27] showed that Vibrio furnssii $\beta$-GlcNAcidase (exol) hydrolyzed $p$ NP-GlcNAc about 5 -fold faster than $\mathrm{GlcNAc}_{2}$, but 1.4 fold slower than GlcNAc $\mathrm{C}_{3-6}$, whereas Kubota et al. [28] reported that Streptomyces thermoviolacacus NagC could hydrolyze $p$ NP-GlcNAc and $\mathrm{GlcNAc}_{2}$ at equal rates. On the other hand, its activity with the $p$ NP substrate was between 2- to 3.5fold greater than with $\mathrm{GlcNAc}_{3-5}$.

\section{Time course of chitin oligosaccharide hydrolysis by TLC and HPLC}

Degradation patterns of chitooligosaccharides by $V h N a g 2$ were analyzed by TLC (Fig. 4). The most significant result obtained from TLC analysis is that $V h \mathrm{Nag} 2$ acted exolytically, yielding GlcNAc as the end product from all chitin oligomers. Additionally, $\mathrm{GlcNAc}_{3}$ and GlcNAc $_{4}$ were degraded rapidly and almost completely within $10 \mathrm{~min}$ (Fig. 4B and 4C), whilst the reaction of
GlcNAc $_{5}$ was not complete until $1 \mathrm{~h}$ of incubation (Fig. 4D). The degradation of GlcNAc 2 (Fig. 4A) and GlcNAc $_{6}$ (Fig. 4E) was even slower, complete hydrolysis of these two substrates being attained only after $2 \mathrm{~h}$ of incubation.

The time course of chitin oligosaccharide hydrolysis by $V h N a g 2$ was further investigated by quantitative HPLC. Fig. 5A shows GlcNAc 2 hydrolysis, showing a rapid increase of the resultant product (GlcNAc) with increasing reaction time. Fig. 5B and Fig. 5C show $\mathrm{GlcNAc}_{3}$ and $\mathrm{GlcNAc}_{4}$ hydrolysis. In agreement with the TLC results, GlcNAc $c_{3}$ and $\mathrm{GlcNAc}_{4}$ were consumed more rapidly than $\mathrm{GlcNAc}_{2}$ (Fig. 5A), GlcNAc ${ }_{5}$ (Fig. 5D) and $\mathrm{GlcNAc}_{6}$ (Fig. 5E). At the end of recording (180 min), no substrate was left from the digestion of GlcNAc $_{3}$ and GlcNAc 4 , whereas substantial amounts of the other substrates remained. All substrates were hydrolyzed exolytically, so that GlcNAc $n$ was degraded to GlcNAc $_{n-1}+$ GlcNAc. The intermediate products, such as GlcNAc $_{n-1}$ and GlcNAc $c_{n-2}$, were further degraded to the final product GlcNAc. Fig. 5F shows the overall rates of hydrolysis to be in the order: $\mathrm{GlcNAc}_{4} \cong \mathrm{GlcNAc}_{3}>\mathrm{GlcNAc}_{5}>\mathrm{GlcNAc}_{6}>\mathrm{GlcNAc}_{2}$. The substrate-size dependence of the reaction rate can be confirmed from the reaction time-course of extensive hydrolysis of $\mathrm{GlcNAc}_{6}$ over a longer period of incubation (1,500 min (25 h), the upper right panel of Fig. 6); that is, chitin pentamer and dimer accumulated during the course of the reaction, whereas tetramer and trimer were generated only transiently before being hydrolyzed instantaneously by the enzyme. Of the natural glycosides, GlcNAc $_{4}$ was found to be the best substrate for $V h N a g 2$. Similar results were reported for $\beta$-GlcNAcidase (exol) from Vibrio furnssii [27]. This enzyme

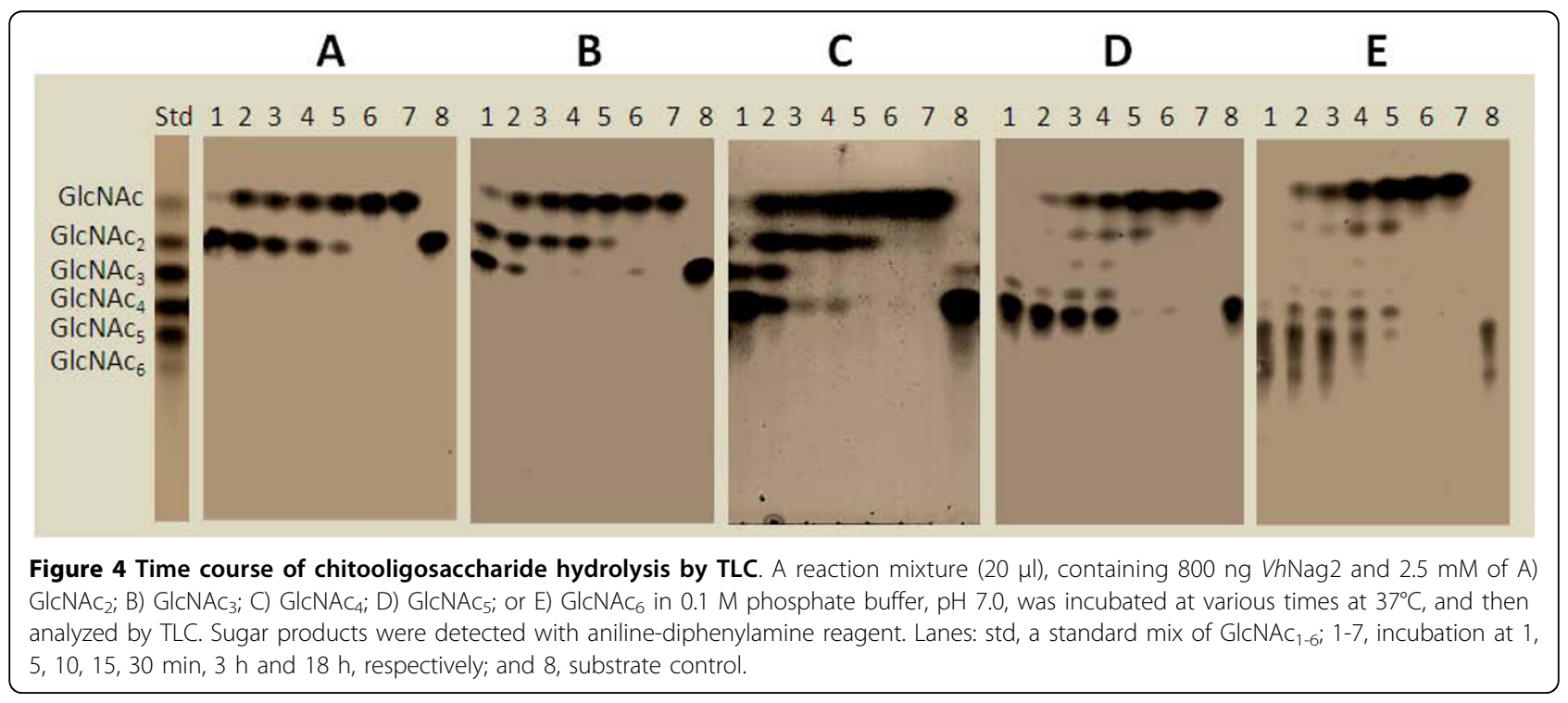



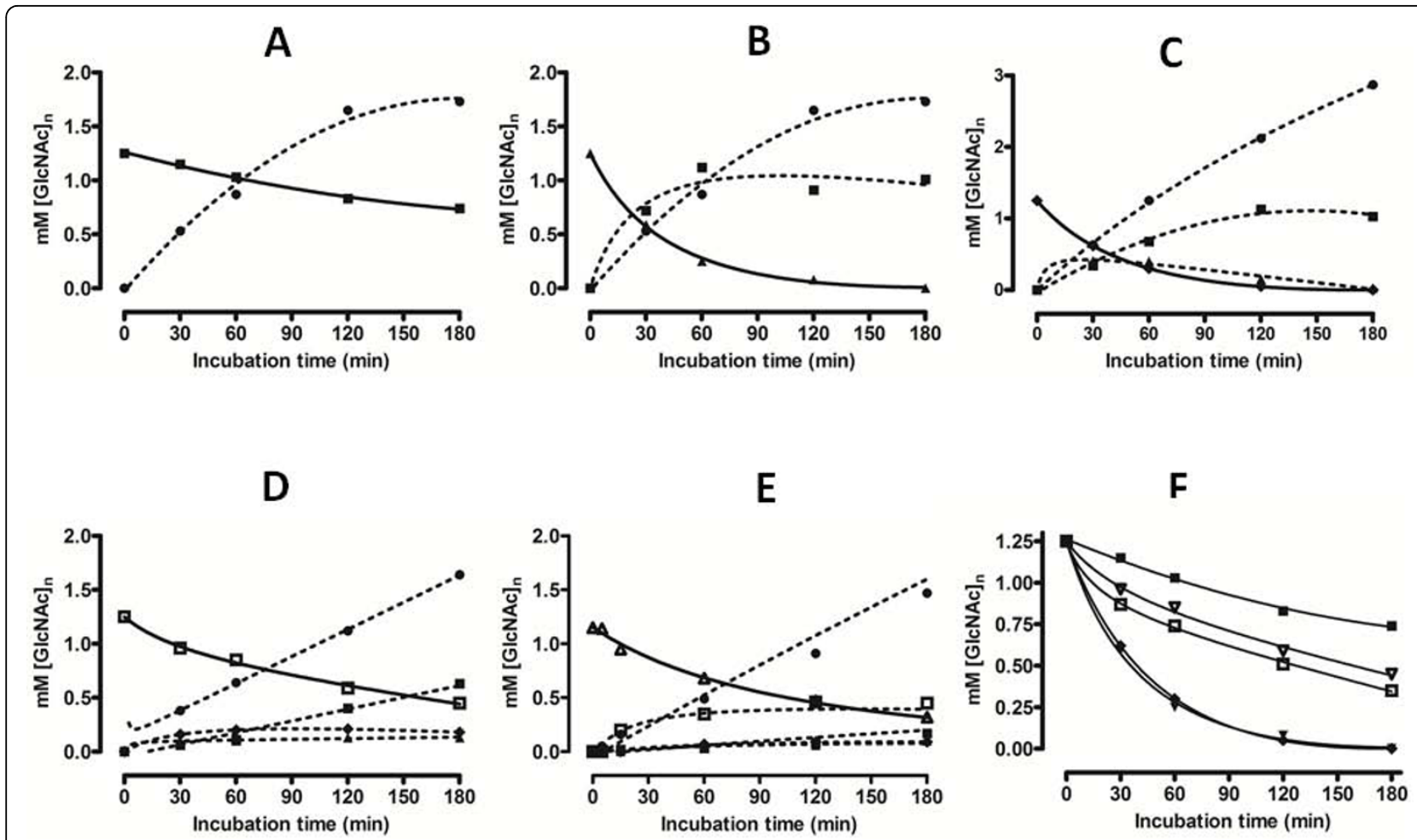

Figure 5 Product analysis of by quantitive HPLC. Purified VhNag2 (50 ng) was added to a reaction mixture containing $5 \mathrm{mM}$ (GlcNAc) in 0.2 $\mathrm{M} \mathrm{mM}$ phosphate buffer, $\mathrm{pH}$ 7.0. The mixture was quenched after the indicated reaction times at $30^{\circ} \mathrm{C}$ by the addition of $0.1 \mathrm{M} \mathrm{NaOH}$ and applied to calibrated HPLC. For each substrate (solid line), the calculated concentrations of the products formed (broken line) are shown. Plots

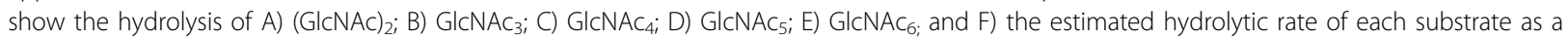
function of time. Substrates and products are represented by (GlcNAc) (black circle); (GlcNAc) 2 (black square); (GlcNAc) 3 (black triangle); (GlcNAc) 4

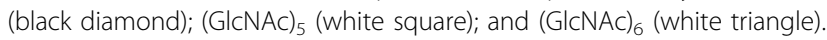

showed its highest $V_{\max }$ towards $\mathrm{GlcNAc}_{4}$, while the $V_{\max }$ values decreased 1.1-fold with $\mathrm{GlCNAc}_{3}$ and 1.4fold with $\mathrm{GlCNAc}_{2}$. Further sequence analysis suggested no putative signal peptide in the sequences of $V h N A g 1$ and $V h N a g 2$. Therefore, the two enzymes are suggested to be non-secretory proteins that act intracellularly. In bacterial cells, the transport of chitin oligomers into the intracellular compartments for further degradation by these GlcNAcases could be achieved by specific membrane transporters. It has been proposed for $V$. furnissii that the uptake of short-chain chitooligosaccharides, such as GlcNAc $_{3}$ and GlcNAc $_{4}$, takes place through a chitooligosaccharide-specific channel known as chitoporin $[29,30]$.

\section{Kinetic modeling and subsite mapping}

Kinetic modeling of the enzymic reaction was carried out based on the reaction scheme presented in Fig. 7. To model the time-course of GlcNAc 6 hydrolysis (shown in the upper panels of Fig. 6), numerical calculations were conducted using the differential equation derived from the reaction scheme [31]. At first, the binding free energy changes for the subsites from $(-1)$ to
$(+4)$ were estimated roughly by repeating the calculations with various values of the free energy changes. Starting with initial guessed values, optimization of the free energy changes conducted by the modified Powell method [32] was employed using the cost function,

$$
F=\sum_{i} \sum_{n}\left[(\mathrm{GlcNAc}) c_{n, i}-(\mathrm{GlcNAc}) e_{n, i}\right]^{2}
$$

where $e$ and $c$ represent the experimental and calculated values, respectively, $n$ is the number of GlcNAc units in the oligosaccharides, and $i$ the reaction time.

The final iteration of the calculations yielded the values of the rate constants for glycosidic bond cleavage $\left(k_{+1}\right)$ for various chain lengths of $\mathrm{GlcNAc}_{\mathrm{n}}$. The $k_{\text {cat }}$ values obtained were allocated to $k_{+1}$ for individual oligosaccharide substrates (Table 1 ). The individual $k_{+1}$ values were fixed in the modeling calculation. Since no evidence for transglycosylation was obtained from HPLC determination of the enzymic products, this process was not considered in the kinetic model. A much higher value of $50 \mathrm{~s}^{-1}$ was tentatively allocated to the rate constant for hydration $k_{+2}$. Since $V h N a g 2$ splits off a 


\section{Experimental time-courses}

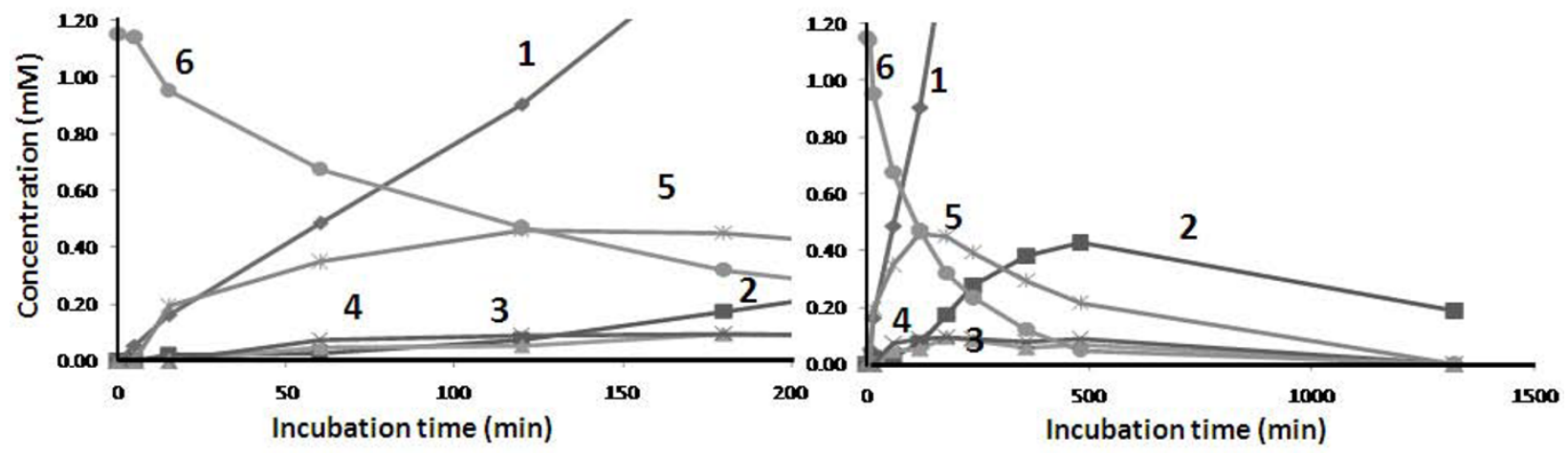

Calculated time-courses
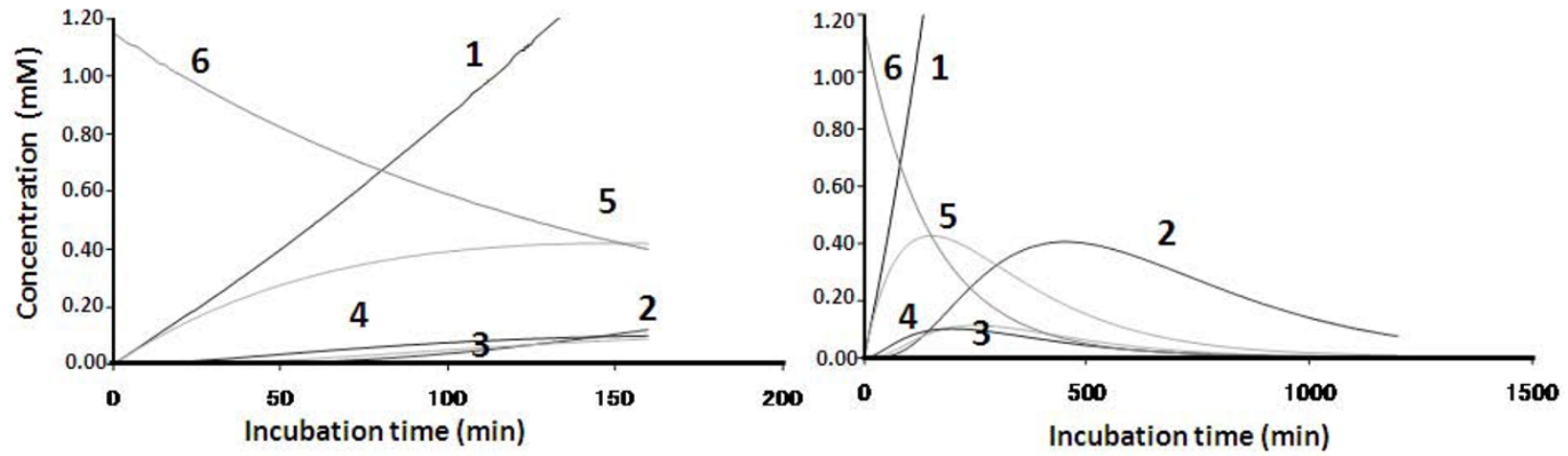

Figure 6 Time-course of GICNAC $_{6}$ hydrolysis catalyzed by VhNag2. Upper panels: Experimental time-courses obtained by HPLC determination. The early stage of the reaction time-course is shown in the left panel, and the later stage is shown in the right panel. The reaction conditions are described in the text. Lower panels: Calculated time-courses best fitted to the experimental ones. The calculation was conducted using the rate constants and binding free energy values listed in Table 2.

monosaccharide from the non-reducing end of the substrate, indicating that subsite $(-2)$ should be the most unfavorable for binding of the GlcNAc residue, we tentatively allocated a high positive value $(+7.0 \mathrm{kcal} / \mathrm{mol})$ to the binding free energy change at subsite $(-2)$. Using the fixed values of $k_{+1}, k_{+2}$, and the binding free energy change of subsite $(-2)$, the values of binding free energies of individual subsites from $(-1)$ to $(+4)$ were optimized on the basis of the experimental time-course (upper panels of Fig. 6). As shown in lower panels of Fig. 6, the calculated time-courses were satisfactorily fitted to the experimental ones, for both the early stage (left panels) and the later stage (right panels) of the reaction, yielding the binding free energy changes of the individual subsites as listed in Table 2.

The TLC and kinetic data suggested that the catalytic pocket of $V h N a g 2$ probably contains a sequence of four favorable GlcNAc binding subsites, designated $(-1)(+1)$ $(+2)(+3)$. Such an implication is certainly supported by the binding free energy changes obtained by the kinetic modeling. As shown in Table 2, a very high positive value $+7.0 \mathrm{kcal} / \mathrm{mol}$ for subsite $(-2)$ suggests that there is a large steric hindrance interfering with binding at this subsite. A less positive value of $+0.9 \mathrm{kcal} / \mathrm{mol}$ of subsite $(+4)$ suggests that the sugar residue binding to this subsite is moderately unfavorable, but still possible. Thus, GlcNAc 4 binds to $(-1)(+1),(+2)$, and $(+3)$ more strongly than GlcNAc $_{5}$ to $(-1)(+1),(+2),(+3)$ and $(+4)$. A low negative free energy change, $-0.1 \mathrm{kcal} / \mathrm{mol}$, was estimated for binding at subsite $(+3)$. This is consistent with the fact that the $\mathrm{GlcNAc}_{3}$ binding affinity to the subsites $(-1)(+1)$, and $(+2)\left(K_{\mathrm{m}}=441 \mu \mathrm{M}\right)$ is somewhat weaker than that of the GlcNAc 4 binding to $(-1)(+1)$, $(+2)$, and $(+3)\left(K_{\mathrm{m}}=329 \mu \mathrm{M}\right)$. All of these results clearly indicate that an array of four GlcNAc binding subsites $(-1)(+1)(+2)(+3)$ define the substrate affinity of $V h N a g 2$. It appears that the GlcNAcases reported to date possess two major types of substrate specificity. The first type has marked preference towards chitobiose, while the other type favours chitooligomers $\left(\mathrm{GlcNAc}_{3-6}\right)$ over chitodimer. Examples of the former type are hyperthermophilic kodakaraensis KOD1 GlmA $\mathrm{TK}_{\mathrm{TK}}$ [33], 


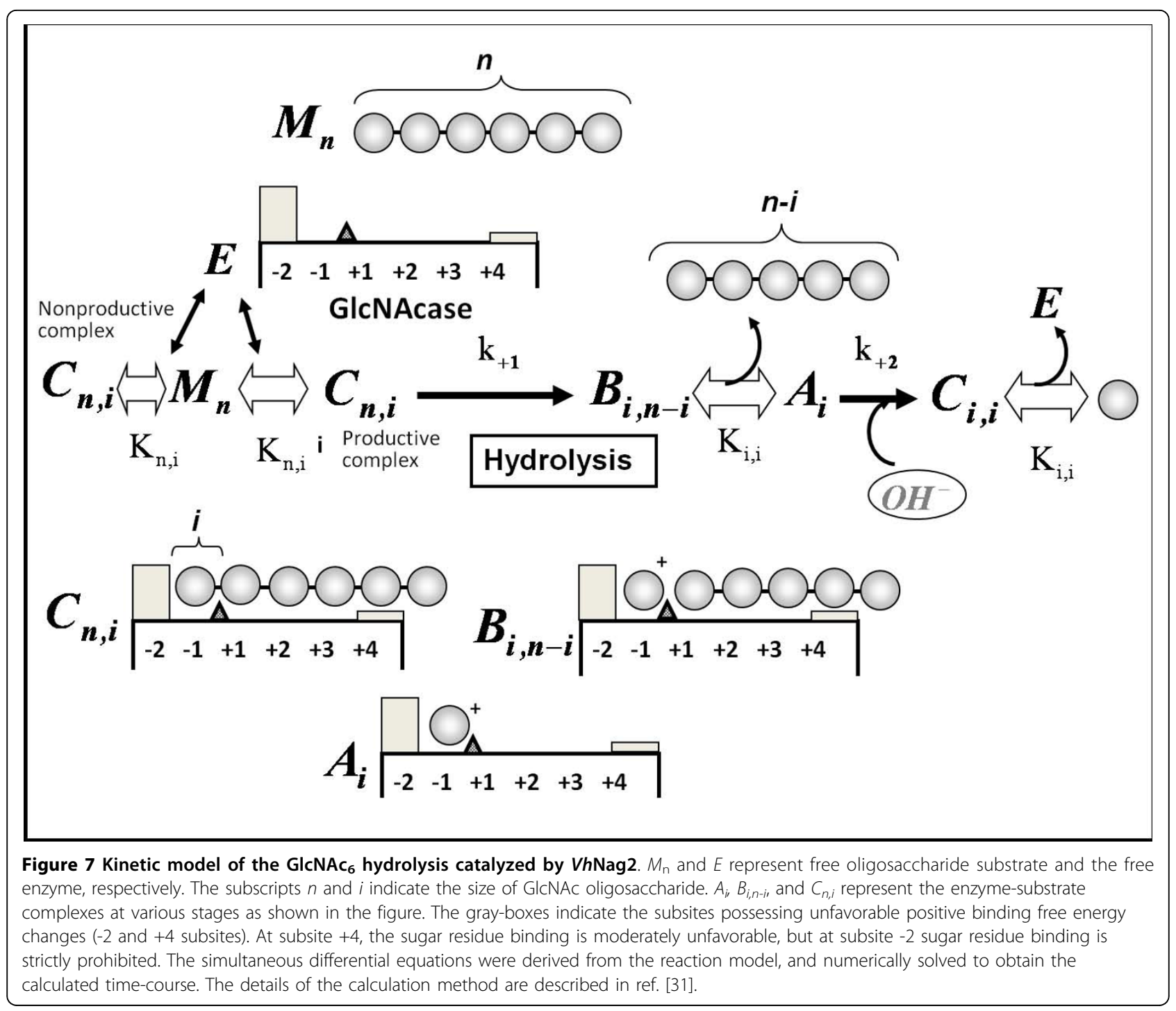

SmChb [25], and S. thermoviolacacus NagC [28]. On the other hand, $V$. furnissii exoI [27], human di- $N$-acetylchitobiase [34], and $V h \mathrm{Nag} 2$ (in this report) are among the other type. The active site of the second type of GlcNAcases has been demonstrated to contain three to five GlcNAc binding subsites, depending on the substrate specificity of individual enzymes. Multiple sugar-binding-site architecture is not uncommon, as has been demonstrated for other exo-glycosidases such as

Table 2 The rate constants and the binding free energy changes estimated from the kinetic modeling calculation

\begin{tabular}{lll}
\hline Substrate & Rate constant $\left(\mathrm{s}^{-1}\right)$ & Binding free energy $(k \mathrm{cal} \mathrm{mol}$ \\
\end{tabular}

\begin{tabular}{cccccccccc}
\cline { 2 - 7 } & $k_{+1}$ & $k_{-1}$ & $k_{+2}$ & $(-2)$ & $(-1)$ & $(+1)$ & $(+2)$ & $(+3)$ & $(+4)$ \\
\hline
\end{tabular}

\begin{tabular}{llllllllll}
\hline GlCNAC $_{4-6}$ & $0.07-0.1$ & 0.0 & 50.0 & +7.0 & -4.5 & 0.0 & -1.1 & -0.1 & +0.9
\end{tabular}

The optimization was based on the experimental time-course of hexamer hydrolysis catalyzed VhNag2 (upper panels of Fig. 6).
Aspergillus niger cellobiase [35], a GH-3 enzyme that degrades cellobioase and cello-oligosaccharides into glucose units. The catalytic center of this enzyme has been reported to contain up to five binding subsites. Also, structural studies of the active site of Bacillus halodurans C-125 REX [36], a GH-8 exo-oligoxylanase that hydrolyzes xylooligosaccharides to xylose from the reducing end, revealed three substrate binding subsites.

\section{Conclusions}

This study reports the isolation, cloning and recombinant expression of the genes encoding two intracellular GH-20 GlcNAcases from a marine bacterium, Vibrio harveyi type strain 650. Data obtained from TLC and quantitative HPLC suggested that the active GlcNAcase homolog (VhNag2) was an exolytic enzyme that degraded chitin oliogmers, releasing GlcNAc as the end product. Kinetic modeling suggested that the active site 
of VhNag2 comprises four GlcNAc binding subsites, $(-1),(+1),(+2),(+3)$. Such subsite identification is strongly supported by kinetic data, which showed chitin tetramer as the most effective substrate for this enzyme.

\section{Methods}

\section{Bacterial strains and vectors}

$V$. harveyi type strain 650 was a marine isolate from Greek sea bass and was a gift from Professor Brian Austin, Heriot-Watt University, Edinburgh, United Kingdom. E. coli strain DH5 $\alpha$ was used for routine cloning and plasmid preparations. $\mathrm{pGEM}^{\circ}-\mathrm{T}$ easy vector used for subcloning purpose was a product of Promega (Promega Pte Ltd, Singapore Science Park I, Singapore). The pQE 60 expression vector and $E$. coli type strain M15 (Qiagen, Valencia, CA, USA) were used for cloning and a high-level expression of recombinant GlcNAcases.

\section{Cloning of the DNAs encoding VhNag1 and VhNag2}

Three sets of oligonucleotide primers were designed based on the three putative GlcNAce genes, designated VIBHAR_01265, VIBHAR_03430, VIBHAR_06345) from $V$. harveyi type strain ATCC BAA-1116 in the CAZy database. However, only two PCR products, namely VhNag1 and VhNag2, were successfully amplified from the genomic DNA of $V$. harveyi type strain 650 . The oligonucleotides used for amplification of VhNag1 DNA are 5'-AGGATCCGGGCAGGGTAAAATC-3' for the forward primer and 5'-AGGAGATCTATCGGTTAAAGTGTGAAG-3' for the reverse primer. For VhNag2 DNA, 5'-AGGGATCCGAATACCGTGTTGATTTA-3' was used as the forward primer and 5'AATAGATCTCTTCCACGGTTTACGGTA-3' for the reverse primer. The PCR products of expected sizes (2.3 kbp for VhNag1 and $1.9 \mathrm{kbp}$ for VhNag2) were cloned in the pQE60 expression vector using $B a m \mathrm{H} \mathrm{I}$ and $B g l$ II cloning sites (sequences underlined) following the protocol supplied by the manufacturer.

\section{Nucleotide, amino acid sequence and phylogenic analyzes}

The nucleotide sequences of VhNAg1 and VhNag2 were determined by automated double stranded DNA sequencing (Bio Service Unit, Thailand Science Park, Bangkok, Thailand). Ambiguous nucleotides were re-confirmed twice before submission to the Genbank database. The amino acid sequence alignment was constructed using "CLUSTALW" algorithm commercially available in Lasergene v.7 (DNASTAR, Inc., WI, USA) and displayed using the Genedoc program (http://www.psc.edu/ biomed/genedoc/). The putative sequences of VhNag1 and $\mathrm{VhNag} 2$ were aligned with the previously published $V$. harveyi chitobiase [26] together with four bacterial and two human GlcNAcases of known structures.

\section{Protein expression and purification}

The full-length VhNag1 and VhNag2 DNAs were cloned into pQE60 expression vector and expressed in E. coli M15 host as the $C$-terminally (His) ${ }_{6}$-tagged polypeptides. The cells were grown at $37^{\circ} \mathrm{C}$ in Luria Bertani (LB) medium containing $100 \mu \mathrm{g} / \mathrm{ml}$ ampicillin until the $\mathrm{OD}_{600}$ of the cell culture reached 0.6. Expression was induced by the addition of isopropyl thio- $\beta$-D-galactoside (IPTG) to a final concentration of $0.5 \mathrm{mM}$. After 18 $\mathrm{h}$ of induction at $20^{\circ} \mathrm{C}$, the cell pellet was collected by centrifugation, re-suspended in lysis buffer $(20 \mathrm{mM}$ Tris- $\mathrm{HCl}$ buffer, $\mathrm{pH} 8.0$, containing $150 \mathrm{mM} \mathrm{NaCl}, 1$ $\mathrm{mM}$ phenylmethylsulphonyl fluoride (PMSF), and 1.0 $\mu \mathrm{g} / \mathrm{ml}$ lysozyme), and then lysed on ice using a Sonopuls Ultrasonichomogenizer with a 6-mm-diameter probe (50\% duty cycle; amplitude setting, 20\%; total time, $30 \mathrm{~s}$, 6-8 times). Unbroken cells were removed by centrifugation at $12,000 \times \mathrm{g}, 20 \mathrm{~min}$ at $4^{\circ} \mathrm{C}$. The supernatant was immediately applied to a Ni-NTA agarose affinity column $(1 \times 10 \mathrm{~cm})$ (QIAGEN GmbH, Hilden, Germany), and the chromatography was carried out under gravity at $4^{\circ} \mathrm{C}$. The column was washed thoroughly with $5 \mathrm{mM}$ imidazole, followed by $20 \mathrm{mM}$ imidazole in equilibration buffer (20 mM Tris-HCl buffer, $\mathrm{pH} 8.0$ ), and then 250 $\mathrm{mM}$ imidazole in the same buffer. Three eluted fractions $(10 \mathrm{ml}$ each) were collected and analyzed by $12 \%$ SDSPAGE [37] to confirm purity. GlcNAcase fractions were pooled and then subjected to several rounds of membrane centrifugation using Vivaspin-20 ultrafiltration membrane concentrators $\left(M_{\mathrm{r}} 10,000\right.$ cut-off, Vivascience AG, Hannover, Germany) for complete removal of imidazole. The final concentration of the protein was determined by Bradford's method [38].

\section{Confirmation of recombinant expression by mass spectrometry}

The purified VhNag1 and VhNag2 $(2 \mu \mathrm{g})$ were applied in parallel onto a $12 \%$ SDS-PAGE gel, and stained with Coomassie blue R-250 after electrophoresis. After destaining, protein bands were subjected to in-gel digestion with trypsin (sequencing grade, Promega) using a standard protocol [39]. The resultant peptides were analyzed by high resolution nanoESI/FTMS by the mass spectrometry facility located at the Max-Planck Institute for Molecular Physiology, Dortmund. Data bank searching was performed with "Mascot search" (http://www. matrixscience.com/) for peptide mass fingerprinting.

\section{GlcNAcase activity assays}

GlcNAcase activity was determined spectrophotometrically using $p$ NP-GlcNAc (Sigma-Aldrich Pte Ltd., The Capricorn, Singapore Science Park II, Singapore) as substrate or by a reducing sugar assay using $\mathrm{GlCNAc}_{2-6}$ (AMS Biotechnology (Europe) Ltd, Oxfordshire, UK) 
and colloidal chitin as substrates. For the $p$ NP assay, a $100-\mu \mathrm{l}$ assay mixture contained the protein sample (50 $\mu \mathrm{g}), 125 \mu \mathrm{M} p \mathrm{NP}-\mathrm{GlcNAc}$ ), and $0.065 \mathrm{M}$ phosphate buffer, $\mathrm{pH}$ 7.0 The enzymic reaction was continued for 10 min at $37^{\circ} \mathrm{C}$ before being terminated by the addition of $100 \mu \mathrm{l} 3 \mathrm{M} \mathrm{Na}_{2} \mathrm{CO}_{3}$. The amount of $p$-nitrophenol $(p \mathrm{NP})$ released was determined spectrophotometrically at $405 \mathrm{~nm}$ in a microtiter plate reader (Applied Biosystems, Foster City, CA, USA). Molar concentrations of $p \mathrm{NP}$ were calculated from a calibration curve constructed with $0-20 \mathrm{nmol} p \mathrm{NP}$. For the reducing sugar assay, the reaction mixture $(100 \mu \mathrm{l})$ contained $250 \mu \mathrm{M}$ GlcNAc $_{2-6}$ in $0.1 \mathrm{M}$ phosphate buffer, $\mathrm{pH} 7.0$ and 200 $\mu \mathrm{g}$ enzyme or $500 \mu \mathrm{M} p \mathrm{NP}$-glycoside in $0.1 \mathrm{M}$ phosphate buffer, $\mathrm{pH} 7.0$ and $100 \mu \mathrm{g}$ enzyme. The reaction mixture was incubated at $37^{\circ} \mathrm{C}$ for $15 \mathrm{~min}$ in a Thermomixer comfort (Eppendorf AG, Hamburg, Germany), then heated at $100^{\circ} \mathrm{C}$ for $10 \mathrm{~min}$. The entire reaction mixture was subjected to 3,5-dinitrosalicylic acid (DNS) assay following the protocol described by Miller [40]. Release of the reducing sugars was detected spectrophotometrically at $540 \mathrm{~nm}$ and molar concentrations of the released sugars were estimated using a standard calibration curve of GlcNAc (0-500 nmol). For colloidal chitin, the reaction mixture $(200 \mu \mathrm{l})$, containing $5 \%(\mathrm{w} / \mathrm{v}) \mathrm{col}-$ loidal chitin (prepared according to Hsu and Lockwood, 1975 [41]), $0.1 \mathrm{M}$ phosphate buffer, $\mathrm{pH} 7.0$, and $200 \mu \mathrm{g}$ enzyme, was incubated at $37^{\circ} \mathrm{C}$ for $15 \mathrm{~min}$. After centrifugation at $12,000 \times g$ for $1 \mathrm{~min}$ to precipitate the remaining chitin, the product concentration in the supernatant $(100 \mu \mathrm{l})$ was determined by DNS method as described for $\mathrm{GlcNAc}_{2-6}$.

\section{Effects of pH on the enzymatic activity}

A discontinuous assay was used to determine the $\mathrm{pH}$ profiles of $V h N a g 1$ and $V h N a g 2$. The reaction mixtures containing $500 \mu \mathrm{M} p \mathrm{NP}-\mathrm{GlcNAc}$ were pre-incubated at $37^{\circ} \mathrm{C}$ for $5 \mathrm{~min}$ at different $\mathrm{pH}$ values ranging from 2.5 to 9.0 using the McIlvaine's sodium phosphate-citric acid - $\mathrm{KCl}$ buffer system [42], followed by addition of 1 $\mu \mathrm{g} V h \mathrm{Nag} 1$ or $0.5 \mu \mathrm{g} V h \mathrm{Nag} 2$. After $10 \mathrm{~min}$ of incubation, the reactions were terminated with $100 \mu \mathrm{l}$ of $3 \mathrm{M}$ $\mathrm{Na}_{2} \mathrm{CO}_{3}$. The amounts of $p \mathrm{NP}$ released were estimated as described for the $p \mathrm{NP}$ assay.

\section{Time course of substrate analysis by thin-layer chromatography}

Hydrolysis of chitooligosaccharides $\left(\mathrm{GlcNAc}_{2-6}\right)$ by $V h \mathrm{Nag} 2$ was carried out in a $20-\mu \mathrm{l}$ reaction mixture, containing 0.1 M phosphate buffer, pH 7.0, $2.5 \mathrm{mM}$ substrate and $5 \mu \mathrm{g}$ purified enzyme. The reaction mixture was incubated at $30^{\circ} \mathrm{C}$ for $1,5,10,15,30 \mathrm{~min}, 3 \mathrm{~h}$ or 18 $\mathrm{h}$, and the reaction terminated by boiling for $5 \mathrm{~min}$. For product analysis, five $1-\mu \mathrm{l}$ aliquots of each reaction mixture were applied to a silica TLC plate $(7 \times 10 \mathrm{~cm})$, and then chromatographed three times ( $1 \mathrm{~h}$ each) in a mobile phase containing $n$-butanol:methanol:28\% ammonia solution: $\mathrm{H}_{2} \mathrm{O}(10: 8: 4: 2)(\mathrm{v} / \mathrm{v})$, followed by spraying with aniline-diphenylamine reagent and baking at $180^{\circ} \mathrm{C}$ for $3 \mathrm{~min}$. To determine the time course of chitin hydrolysis, the reaction was carried out in a 150$\mu \mathrm{l}$ reaction mixture, containing $0.1 \mathrm{M}$ phosphate buffer, $\mathrm{pH} 7.0,20 \mathrm{mg}$ colloidal chitin, and $50 \mu \mathrm{g}$ purified enzyme. Subsequent reactions and determination of the reaction products were analyzed by TLC as described for chitooligosaccharide hydrolysis.

\section{Time-course analysis of chitooligosaccharide hydrolysis by HPLC}

A reaction mixture $(100 \mu \mathrm{l})$ containing $1.25 \mathrm{mM}$ chitin oligosaccharide ( $\mathrm{GlcNAc}_{2-6}$ ), $38 \mu \mathrm{M} V h \mathrm{Nag} 2$ and $0.2 \mathrm{M}$ sodium phosphate buffer, $\mathrm{pH} 7.0$ was incubated at $30^{\circ} \mathrm{C}$. An aliquot of $12 \mu \mathrm{l}$ was transferred to a new microfuge tube containing $12 \mu \mathrm{l} 0.1 \mathrm{M} \mathrm{NaOH}$ after $5,10,15,30,60$, 120 and $180 \mathrm{~min}$, and the enzymic reaction was stopped by snap-freezing in liquid $\mathrm{N}_{2}$ and the mixture immediately stored at $-20^{\circ} \mathrm{C}$. To quantitatively determine the time-course of substrate degradation and product formation, $15-\mu \mathrm{l}$ of the reaction mixture was applied to a gelfiltration column of TSK-GEL G2000PW $(7.5 \times 600 \mathrm{~mm}$, Tosoh) connected with a Hitachi L-7000 HPLC system (Hitachi Koki Co., Ltd, Tokyo). Elution was conducted with distilled water at a flow rate of $0.3 \mathrm{ml} / \mathrm{min}$, and the substrate and products were monitored by their absorption at $220 \mathrm{~nm}$. Based on the peak areas obtained from the elution profiles, oligosaccharide concentrations were calculated using a standard curve obtained with authentic saccharide solutions, and then plotted against the reaction time to obtain the reaction time-course.

\section{Steady-state kinetics}

Kinetic parameters were determined using $p$ NP-GlcNAc and chitooligosaccharides $\left(\mathrm{GlcNAc}_{2-6}\right)$ by the reducing sugar assay as described above, with $0-500 \mu \mathrm{M}$ of each substrate in the reaction mixture. The amounts of the reaction products were determined from a standard curve of GlcNAc $(0-1.75 \mu \mathrm{mol})$. Kinetic parameter values were evaluated from three independent sets of data using the nonlinear regression function obtained from the GraphPad Prism v.5.0 (GraphPad Software Inc., San Diego, CA).

\section{Kinetic modeling of substrate hydrolysis}

Kinetic modeling of the reaction time-course obtained by HPLC was carried out using the reaction model reported for the Coccidioides immitis family 18 chitinase [43]. The model scheme is shown in Fig. 7. Considering that the enzyme hydrolyzes the oligosaccharide substrate 
exolytically from the non-reducing end, $V h N a g 2$ was assumed to have a $(-2)(-1)(+1)(+2)(+3)(+4)$-type binding cleft, where subsite $(-2)$ should have an unfavorable (positive) binding free energy change. By assuming rapid binding equilibrium, the concentrations of the ES-complexes formed through the individual binding modes $\left(C_{n}\right.$, ${ }_{i}, \mathrm{~B}_{i, j}$, and $\mathrm{A}_{i}$ ) were calculated from the binding constants, which were obtained from the binding free energy values of individual subsites occupied with the sugar residues assuming additivity. Details of the calculation method were described by Honda and Fukamizo [31].

\section{Additional material}

\section{Additional file 1: Table S1 Identification of $v$. harveyi GlcNAcases by} mass spectrometry. Tryptic peptides of VhNag1 and VhNAg2 were resolved and detected by nano-HPLC/ESI-FTMS. Mascot search subsequently identified the resultant peptides of $\beta \beta$-N-acetyl glucosaminidases from the NCBINr database.

Additional file 2: Fig. S1 The reaction progress curve of $V h N a g 1$ and VhNag2 using $p N P-G I C N A c$ as substrate. The reaction mixtures $(200 \mu \mathrm{l})$ containing $250 \mu \mathrm{M}$ pNP-GlcNAc, $10 \mu \mathrm{g}$ VhNag1 or $5 \mu \mathrm{g}$ VhNag2, and $0.1 \mathrm{M}$ sodium phosphate buffer, $\mathrm{pH} 7.0$ were incubated at $37^{\circ} \mathrm{C}$ for $5,10,15,30,45,60$ and $180 \mathrm{~min}$. After the specified time the reaction was terminated by the addition of $100 \mu \mathrm{l} 3 \mathrm{M} \mathrm{Na}_{2} \mathrm{CO}_{3}$. The release of pNP was determined as described in the main text.

\section{Abbreviations}

GICNAC $_{n}$ or NAG: $\beta \beta 1$-4 linked oligomers of $N$-acetylglucosamine residues where $n=1-6$; GlcNAcase: $\beta \beta$ - $N$-acetyl-glucosaminidase; DNS: 3,5dinitrosalicylic acid; $p N$ N-GICNAc: $p$-nitrophenyl- $\beta \beta$-D- $N$-acetylglucosaminide; IPTG: isopropyl thio- $\beta \beta$-D-galactoside; ORFs: open reading frames; PMSF: phenylmethylsulphonylfluoride; TLC: Thin Layer Chromatography. This work was financially supported by Suranaree University of Technology (Grant no SUT1-102-52-24-08). We are grateful to P. Janning and A. Brockmeyer, Max Planck Institute of Molecular Physiology, Dortmund, for nano-HPLC/ESI-FTMS measurements and associated data interpretation.
\end{abstract}

\section{Author details}

'Biochemistry-Electrochemistry Research Unit, Schools of Chemistry and Biochemistry, Institute of Science, Suranaree University of Technology, Nakhon Ratchasima 30000, Thailand. 'Department of Advanced Bioscience, Kinki University, 3327-204 Nakamachi, Nara 631-8505 Japan.

\section{Authors' contributions \\ WS initiated the research, was responsible for the theme setting, primer design and site-directed mutagenesis. She also carried out HPLC experiments, performed analysis and interpretation of the kinetic, TLC and HPLC data, and also prepared and finalized the manuscript. DC carried out genomic DNA isolation, cloning, recombinant expression, protein purification, TLC and kinetic experiments. MM performed the calculation of the rate constants and binding free energy changes. TF provided guidance on quantitative HPLC, theoretical analysis and deduction of the reaction scheme. He also edited and proofread the manuscript. All authors read and approved the final manuscript.}

Received: 4 May 2010 Accepted: 29 September 2010 Published: 29 September 2010

\section{References}

1. Wu GJ, Tsai GJ: Chitooligosaccharides in combination with interferon-c increase nitric oxide production via nuclear factor-jB activation in murine RAW264.7 macrophages. Food Chem Toxicol 2007, 45:250-258.
2. Vishu Kumar $A B$, Varadaraj MC, Gowda LR, Tharanathan RN: Characterization of chito-oligosaccharides prepared by chitosanolysis with the aid of papain and pronase, and their bactericidal action against Bacillus cereus and Escherichia coli. Biochem J 2005, 391:167-175.

3. Sharon N: Carbohydrates as future anti-adhesion drugs for infectious diseases. Biochim Biophys Acta 2006, 1760:527-537.

4. Friedman SJ, Skehan P: Membrane-active drugs potentiate the killing of tumor cells by D-glucosamine. Proc Natl Acad Sci USA 1980, 77:1172-1176.

5. Shen KT, Chen MH, Chan HY, Jeng JH, Wang YJ: Inhibitory effects of chitooligosaccharides on tumor growth and metastasis. Food Chem Toxicol 2009, 47:1864-1871.

6. Patil SR, Ghormade V, Deshpande MV: Chitinolytic enzymes: an exploration. Enzyme Microb Technol 2000, 26:473-483.

7. Kornfeld R, Kornfeld DS: Assembly of asparagine-linked oligosaccharides. Annu Rev Biochem 1985, 54:631-664.

8. Karamanos Y, Bourgerie S, Barreaud JP, Julien R: Are there biological functions for bacterial endo-N-acetyl-beta-D-glucosaminidases? Res Microbiol 1995, 146:437-443.

9. Myerowitz R: Tay-Sachs disease-causing mutations and neutral polymorphisms in the Hex A gene. Hum Mutat 1997, 9:195-208.

10. Henrissat B, Bairoch A: New families in the classification of glycosyl hydrolases based on amino-acid sequence similarities. Biochem J 1993, 293:781-788.

11. Henrissat B, Davies G: Structural and sequence-based classification of glycoside hydrolases. Curr Opin Struct Biol 1997, 7:637-644

12. Vocadlo DJ, Withers SG: Detailed comparative analysis of the catalytic mechanisms of beta- $N$-acetylglucosaminidases from families 3 and 20 of glycoside hydrolases. Biochemistry 2005, 44:12809-12818.

13. Prag G, Papanikolau Y, Tavlas G, Vorgias CE, Petratos K, Oppenheim AB: Structures of chitobiase mutants complexed with the substrate di- $\mathrm{N}$ acetyl-D-glucosamine: the catalytic role of the conserved acidic pair, aspartate 539 and glutamate 540. J Mol Biol 2000, 300:611-617.

14. Williams SJ, Mark BL, Vocadlo DJ, James MN, Withers SG: Aspartate 313 in the Streptomyces plicatus hexosaminidase plays a critical role in substrate-assisted catalysis by orienting the 2-acetamido group and stabilizing the transition state. J Biol Chem 2002, 277:40055-40065.

15. Drouillard S, Armand S, Davies GJ, Vorgias CE, Henrissat B: Serratia marcescens chitobiase is a retaining glycosidase utilizing substrate acetamido group participation. Biochem J 1997, 328:945-949.

16. Chitlaru E, Roseman S: Molecular cloning and characterization of a novel beta- $N$-acetyl-D-glucosaminidase from Vibrio furnissii. J Biol Chem 1996, 271:33433-33439.

17. Li H, Morimoto K, Katagiri N, Kimura T, Sakka K, Lun S, Ohmiya K: A novel beta- $N$-acetylglucosaminidase of Clostridium paraputrificum M-21 with high activity on chitobiose. Appl Microbiol Biotechnol 2002, 60:420-427.

18. Tsujibo H, Hatano N, Mikami T, Hirasawa A, Miyamoto K, Inamori Y: A novel beta- $\mathrm{N}$-acetylglucosaminidase from Streptomyces thermoviolaceus OPC520: Gene cloning, expression, and assignment to family 3 of the glycosyl hydrolases. App/ Environ Microbiol 1998, 64:2920-2924.

19. Choi KH, Seo JY, Park KM, Park CS, Cha J: Characterization of glycosyl hydrolase family 3 beta- $N$-acetylglucosaminidases from Thermotoga maritima and Thermotoga neapolitana. J Biosci Bioeng 2009, 108:455-459.

20. Austin B, Zhang $\mathrm{XH}$ : Vibrio harveyi: a significant pathogen of marine vertebrates and invertebrates. Lett Appl Microbiol 2006, 43:119-124.

21. Owens $L$, Busico-Salcedo N: Vibrio harveyi: pretty problems in paradise. In The Biology of Vibrios. Edited by: Thompson FL, Austin B, Swings J. Washington DC, ASM Press; 2006:266-280.

22. Suginta W, Robertson PA, Austin B, Fry SC, Fothergill-Gilmore LA: Chitinases from Vibrios: activity screening and purification of chi A from Vibrio carchariae. J Appl Microbiol 2000, 89:76-84.

23. Suginta W, Vongsuwan A, Songsiriritthigul C, Prinz $H$, Estibeiro $P$, Duncan RR, Svasti J, Fothergill-Gilmore LA: An endochitinase A from Vibrio carchariae: cloning, expression, mass and sequence analyses. Arch Biochem Biophys 2004, 424:171-180.

24. Lemieux MJ, Mark BL, Cherney MM, Withers SG, Mahuran DJ, James MN: Crystallographic structure of human beta-hexosaminidase $A$ : interpretation of Tay-Sachs mutations and loss of GM2 ganglioside hydrolysis. J Mol Biol 2006, 359:913-929.

25. Tews I, Perrakis A, Oppenheim A, Dauter Z, Wilson KS, Vorgias CE: Bacterial chitobiase structure provides insight into catalytic mechanism and the basis of Tay-Sachs disease. Nat Struct Biol 1996, 3:638-648. 
26. Soto-Gil RW, Zyskind JW: N,N'-diacetylchitobiase of Vibrio harveyi. Primary structure, processing, and evolutionary relationships. J Biol Chem 1989, 264:14778-14783.

27. Keyhani NO, Roseman S: The chitin catabolic cascade in the marine bacterium Vibrio furnissii. Molecular cloning, isolation, and characterization of a periplasmic beta- $\mathrm{N}$-acetylglucosaminidase. J BiOl Chem 1996, 271:33425-33432.

28. Kubota T, Miyamoto K, Yasuda M, Inamori Y, Tsujibo H: Molecular characterization of an intracellular beta- $\mathrm{N}$-acetylglucosaminidase involved in the chitin degradation system of Streptomyces thermoviolaceus OPC-520. Biosci Biotechnol Biochem 2004, 68:1306-1314.

29. Keyhani NO, Li XB, Roseman S: Chitin catabolism in the marine bacterium Vibrio furnissii. Identification and molecular cloning of a chitoporin. J Biol Chem 2000, 275:33068-33076.

30. Hunt DE, Gevers D, Vahora NM, Polz MF: Conservation of the chitin utilization pathway in the Vibrionaceae. Appl Environ Microbiol 2008, 74:44-51.

31. Honda $Y$, Fukamizo T: Substrate binding subsites of chitinase from barley seeds and lysozyme from goose egg white. Biochim Biophys Acta 1998, 1388:53-65.

32. Kuhara S, Ezaki E, Fukamizo T, Hayashi K: Estimation of the free energy change of substrate binding lysozyme-catalyzed reactions. J Biochem 1982, 92:121-127.

33. Tanaka T, Fukui T, Atomi H, Imanaka T: Characterization of an exo-beta-Dglucosaminidase involved in a novel chitinolytic pathway from the hyperthermophilic archaeon Thermococcus kodakaraensis KOD1. $J$ Bacteriol 2003, 185:5175-5181.

34. Aronson NN, Halloran BA: Optimum substrate size and specific anomer requirements for the reducing-end glycoside hydrolase di- $\mathrm{N}$ acetylchitobiase. Biosci Biotechnol Biochem 2006, 70:1537-1541.

35. Yazaki T, Ohnishi M: Subsite structure of beta-glucosidase from Aspergillus niger and kinetic mechanism of the beta-glucosidase-catalyzed reactions. In Glycoenzymes. Edited by: Ohnishi M. Japan Scientific Societies Press, Tokyo; 2000:171-187.

36. Fushinobu S, Hidaka M, Honda Y, Wakagi T, Shoun H, Kitaoka M: Structural basis for the specificity of the reducing end xylose-releasing exooligoxylanase from Bacillus halodurans C-125. J Biol Chem 2005, 280:17180-17186.

37. Laemmli UK: Cleavage of structural proteins during the assembly of the head of bacteriophage T4. Nature 1970, 227:680-685.

38. Bradford MM: A rapid and sensitive method for the quantitation of microgram quantities of protein utilizing the principle of protein-dye binding. Anal Biochem 1976, 72:248-254

39. Shevchenko A, Wilm M, Vorm O, Mann M: Mass spectrometric sequencing of proteins silver-stained polyacrylamide gels. Anal Chem 1996, 68:850-858.

40. Miller GL: Use of dinitrosalicylic acid reagent for determination of reducing sugar. Anal Chem 1959, 31:426-428.

41. Hsu SC, Lockwood JL: Powdered chitin agar as a selective medium for enumeration of actinomycetes in water and soil. Appl Microbio/ 1975, 29:422-426.

42. Mcllvaine TC: A buffer solution for colorimetric comparison. J Biol Chem 1921, 49:183-186.

43. Fukamizo T, Sasaki C, Schelp E, Bortone K, Robertus JD: Kinetic properties of chitinase-1 from the fungal pathogen Coccidioides immitis. Biochemistry 2001, 40:2448-2454.

doi:10.1186/1471-2091-11-40

Cite this article as: Suginta et al: Novel $\beta \beta-N$-acetylglucosaminidases from Vibrio harveyi 650: Cloning, expression, enzymatic properties, and subsite identification. BMC Biochemistry 2010 11:40.

\section{Submit your next manuscript to BioMed Central and take full advantage of:}

- Convenient online submission

- Thorough peer review

- No space constraints or color figure charges

- Immediate publication on acceptance

- Inclusion in PubMed, CAS, Scopus and Google Scholar

- Research which is freely available for redistribution

Submit your manuscript at www.biomedcentral.com/submit 